\title{
Penerapan Algoritma Certainty Factor Dan Pemodelan Uml Dalam Merancang Aplikasi Diagnosis Penyakit Gastritis
}

\author{
Andreas Nugraha Putra ${ }^{1}$, Setiaji ${ }^{2}$, Riswandi Ishak ${ }^{3}$ Jamal Maulana Hudin $^{4}$
}

\begin{abstract}
Implementation Centainty Factor Algorthm and UML modelling in designing the application of the diagnosis of Gastritis disease. Ignorance of gastritis disease and the limitation of handling the disease is often experienced by teenagers. Therefore we need for action / treatment quickly to prevent gastritis disease. Gastritis is an inflammatory process in the mucosal layer and gastric submucosa as a mechanism of mucosal protection when there is accumulation of bacteria or other irritant substances. The inflammatory process may be mild (Dyspepsia), moderate (Gerd) and acute Gastritis. Expert system requires a method or rule in solving the problem of gastritis disease is by certainty factor method. The method certainty factor (CF) can defined the size of certainty by the fac or rulest, to describe the level of expert confidence to the problem at hand. Therefore in this study developed expert system that can be accessed through mobile devices such as android phone. The delivery of information was done using a mobile device, so it can be concluded that the research is implemented into the android application. So with the manufacture of expert systems to diagnose gastritis disease can help people, especially in adolescence to know the problems and severity such as mild, chronic gastritis symptoms.
\end{abstract}

Keywords: Expert System, Certainty Factor, Diagnosis of Gastritis Disease

\section{PENDAHULUAN}

Gastritis merupakan proses inflamasi yang terjadi pada bagian lambung yang disebut mukosa dan submukosa proses ini merupakan mekanisme perlindungan pada bagian mukosa apabila terjadi akumulasi bakteri atau bahan iritan lain. Pada penyakit gastritis dapat dikategorikan menjadi 3 jenis diagnosa yaitu sedang (Dyspepsia), ringan (Gerd), dan akut [1]

Kasus penyakit gastritis pada usia remaja di Indonesia angkanya cukup tinggi, berdasarkan data dari Departemen Kesehatan RI angka kejadian gastritis di beberapa kota di Indonesia dengan persentase $91,6 \%$. [2]

Dalam sebuah sistem pakar membutuhkan sebuah metode yang dapat menyelelesaikan masalah daam mendiagnosa penyakit gastritis. Metode certainty factor dapat digunakan untuk mengukur tingkat kepastian terhadap suatu fakta atau aturan dari sebuah sistem pakar. Dengan menggunakan metode ini tingkat keyakinan pakar dapat digambarkan berdasarkan masalah yang dihadapi oleh seorang pakar dalam mencoba mendiagnosa sebuah penyakit sesuai dengan gejala-gejala yang muncul [3]

\footnotetext{
${ }^{I}$ Program Studi Informatika Universitas Nusa Mandiri, Jakarta Timur DKI Jakarta, e-mail: andreas.nugrahaputra@ gmail.com

${ }^{2,3,4}$ Program Studi Sistem Informasi Universitas Bina Sarana Informatika, Jakarta Pusat DKI Jakarta, e-mail: setiaji.sej@bsi.ac.id,riswandi.rik@bsi.ac.id,Jamal.jml@bsi.ac.id
}

Dengan membuat sebuah sistem pakar untuk mendiagnosa penyakit gastritis ini dapat membantu pada remaja atau para penderita penyakit lambung untuk mengetahui permasalahan dan tingkat keparahan serta memberikan cara untuk penanganan bagi para penderita gastritis [4]

\section{METODE PENELITIAN}

A. Pengumpulan Data

1. Observasi atau Tinjauan Langsung

Metode ini digunakan untuk memdapatkan data yang diperoleh dari objek penelitian dengan cara mengamati langsung proses diagnosa penyakit gasitris yang dialami oleh seorang pasien gastritis. Dalam hal ini melakukan konsultasi dengan dokter umum dan pasien pada sebuah klinik merupakan cara yang ditembuh sebagai metode tinjauan langsung.

2. Studi Pustaka

Selanjutnya setelah melakukan observasi penulis juga melakukan motde studi kepustakaan melalui referensireferensi yang diambil dari buku, sumber internet, $e$-books, e-jurnal, dan buku-buku yang berhubungan dengan sistem pakar.

B. Tahapan penelitian

Pada bagian ini dijelaskan tahapan-tahapan penelitian dan juga disertai dengan hasil yang didapatkan pada setiap tahapan penelitian tersebut. Metode pengembangan sistem yang digunakan oleh penulis adalah metode waterfall dimana dalam proses pengembangan sistem, pengumpulan dan pengelolaan data sudah terangkum di dalamnya. [5].

Model pengembangan sangat membantu dalam proses perancangan dan pengembangan sistem dikarenakan proses atau tahapan yang dilakukan secara berurutan[6]

1. Pengembangan Pakar

Metode yang digunakan untuk mengukur sebuah ketidakpastian adalah metode Certainty Factor. Metode ini dapat mengakomodasi tingkat pengukuran terhadap ketidakpastian pemikiran dengan menggambarkan tingkat keyakinan seorang pakar terhadap masalah yang sedang dihadapi [7]

2. Pengembangan Aplikasi

a. Analisa Kebutuhan Perangkat Lunak

Sistem pakar diagnosis penyakit gastritis ini akan diaplikasikan ke dalam bentuk aplikasi berbasi Android yang diterapkan pada perangkat mobile, karena dapat di pergunakan langsung dan mudah tanpa harus bertatap muka dengan seorang pakar dan dengan sistem ini orang bisa mengakses aplikasi dimanapun dan kapanpun.

b. Perancangan Sistem (Sistem Desain) 
Didalam proses desain atau rancangan antar muka dari program sistem pakar ini menggunakan aplikasi bantuan yaitu eclipse dikarenakan sistem yang dibangun berbasis android atau perangkat mobile.

c. Pengkodean

Proses pengkodean yang digunakan dalam merancang aplikasi ini adalah bahasa pemograman Java.

d. Testing

Dalam proses pengujian sistem pakar ini menggunakan teknik black box testing. Dengan pertimbangan bahwa teknik ini dapat menemukan kesalahan dan kestidaksesuaian dari aplikasi pada saat dioperasikan.

e. Maintenance

Tahapan terakhir pada metode waterfall adalah tahapan Maintenance atau disebut pemiliharaan. Pada tahapan ini penuis melakukan pemeriksaan secara berkala terhadap sitem.

\section{HASIL DAN PEMBAHASAN}

A. Algortima Sistem Pakar

Berikut penerapan algoritma Centanty Factor yang digunakan ole penulis [8].

$$
\text { Cfcombine }[\mathrm{CF} 1, \mathrm{CF} 2]=\mathrm{CF} 1+\mathrm{CF} 2 *(1-\mathrm{CF} 1)
$$

B. Basis Pengetahuan

Basis pengetahuan merupakan informasi yang dapat disimpulkan melalui fakta-fakta yang muncul pada proses diagnose dan dapat menyimpulkan suatu fakta baru yang diperoleh dari fakta yang sudah ada atau diketahui.[9]

1. Tabel Pakar

Basis pengetahuan yang terbentuk digambarkan dalam sebuah tabel pakar sebagai berikut:

Tabel 1. Tabel Pakar

\begin{tabular}{llll}
\hline $\begin{array}{l}\text { Gejala Penyakit } \\
\text { Gastritis }\end{array}$ & $\begin{array}{l}\text { Sedang } \\
\text { (Dyspepsia) }\end{array}$ & $\begin{array}{l}\text { Ringan } \\
\text { (Gerd) }\end{array}$ & $\begin{array}{l}\text { Akut } \\
\text { (Gastritis) }\end{array}$ \\
\hline $\begin{array}{l}\text { Rasa pahit pada } \\
\text { kerongkongan }\end{array}$ & 0,3 & & \\
$\begin{array}{l}\text { Rasa panas pada } \\
\text { keringkongan }\end{array}$ & 0,2 & & \\
$\begin{array}{l}\text { Terasa Kembung } \\
\text { pada bagian perut }\end{array}$ & 0,2 & & \\
$\begin{array}{l}\text { Muntah-muntah } \\
\text { Terkadang batuk }\end{array}$ & & & \\
kering & 0,6 & \\
$\begin{array}{l}\text { Bau napas tidak } \\
\text { sedap }\end{array}$ & 0,6 & \\
$\begin{array}{l}\text { Perut terasa mual } \\
\text { Perut terasa sakit }\end{array}$ & & 0,6 & \\
$\begin{array}{l}\text { Cepat merasa } \\
\text { kenyang saat makan }\end{array}$ & & 0,85 \\
\hline Keteangan: & & 0,8 \\
& & & 0.8 \\
\hline
\end{tabular}

Keterangan:

Pada kolom pertama merupakan gejala yang ditimbukan oleh penyakit gastritis, diantaranya:

G01: Rasa pahit pada kerongkongan
G02: Rasa panas di kerongkongan

G03: Terasa kembung pada bagian perut

G04: Muntah-muntah

G05: Terkadang batuk kering

G06: Bau napas tidak sedap

G07: Perut terasa mual

G08: perut terasa sakit

G09: cepat merasa kenyang saat makan

2. Aturan yang berlaku pada aplikasi pakar ini antara lain:

a. Penyakit Gastritis (Dyspepsia)

IF Terasa Pahit pada kerongkongan

AND Rasa panas di kerongkongan

AND Terasa kembung pada bagian perut

THEN Dyspepsia

b. Penyakit Gastritis (Gerd)

IF Muntah-muntah

AND Terkadang Batuk Kering

AND Bau napas tidak sedap

THEN Gerd

c. Penyakit Gastritis Akut

IF Perut terasa Mual

AND Perut terasa sakit

AND Cepat merasa kenyang saat makan

THEN Gastritis Akut

3. Pohon Keputusan Pada Pakar

Berikut gambaran pohon keputusan yang diperoleh berdasarkan aturan-aturan dari pakar :

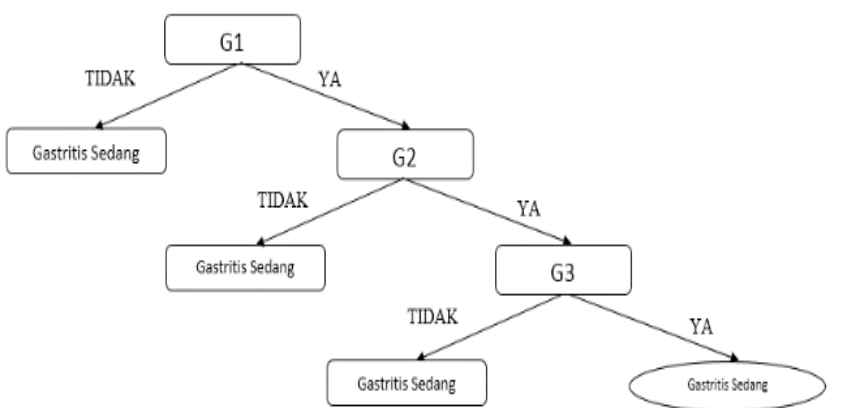

Gambar 1 Pohon Keputusan Gastritis Sedang (Dyspepsia)

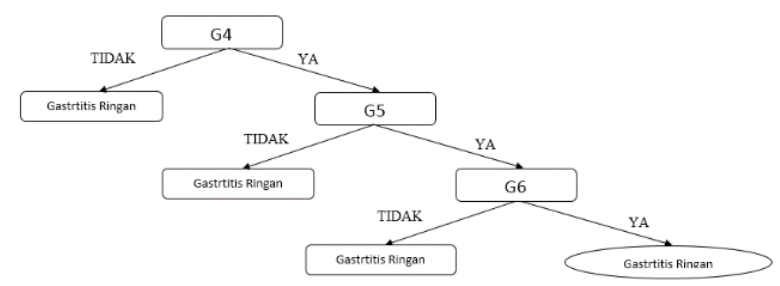

Gambar 2 Pohon Keputusan Gastritis Ringan (Gerd) 


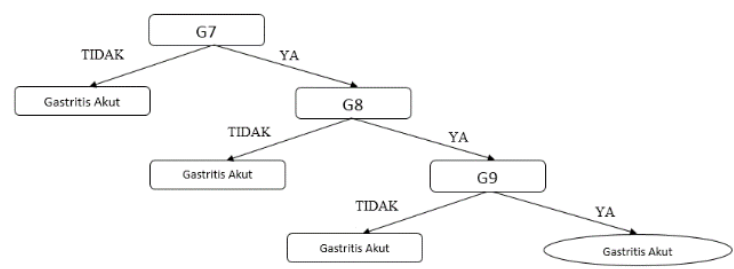

Gambar 3 Pohon Keputusan Gastritis Akut

C. Arsitektur Perangkat Lunak

1. Kode Semu (Pseudocode)

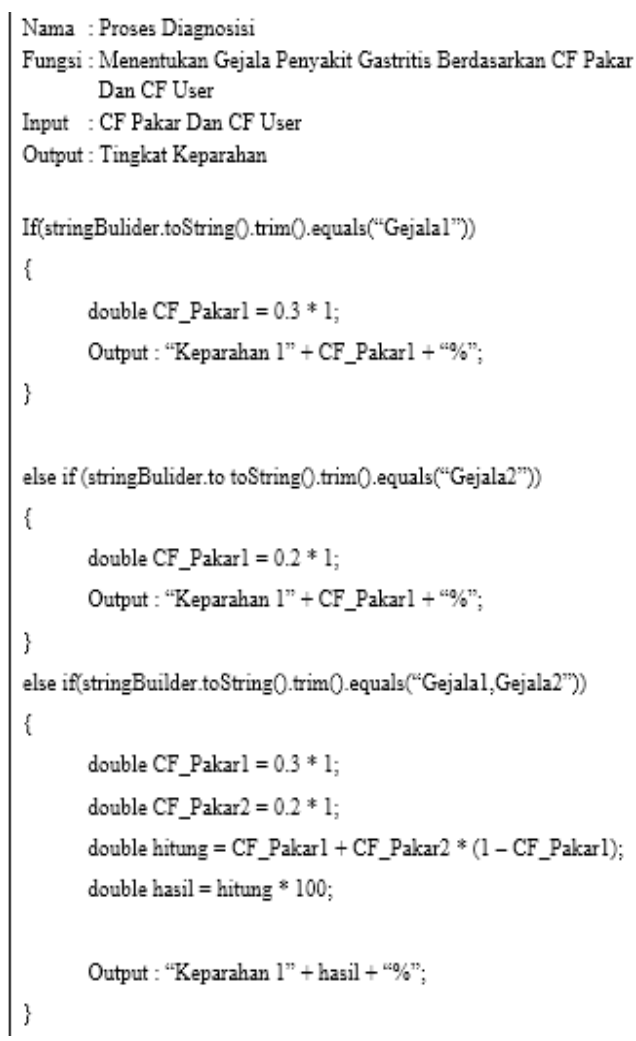

Gambar 4 Pseudocode Proses Diagnosis

2. Permodelan UML

Dalam proses perancangan sistem aplikasi diagnosis gastritis ini penulis menggunakan pemodelan UML antaralain [10].

a. Usecase Diagram

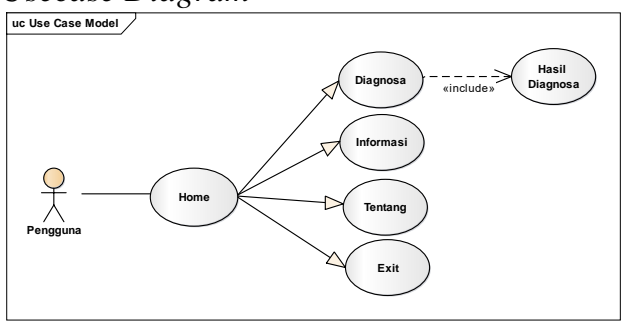

Gambar 5 Use Case Diagram Diagnosis gastritis pada usia remaja

Tabel 2. Use Case Diagram Menu Diagnosa

\begin{tabular}{ll}
\hline Use Case Name & Menu Diagnosa \\
\hline Requirment & A1 \\
Goal & Simtem Menampilkan hasil doagnosa \\
Pre-condition & $\begin{array}{l}\text { Pengguna memilih gejala pada menu } \\
\text { diagnosa }\end{array}$ \\
& Tampil hasil diagnosa \\
Post-condition & Pengguna tidak memilih gejala \\
Failed end condition & Pengguna \\
Primary Actor & Pengguna memilih menu \\
Pain Flow/ Basic & diagnosa \\
Invariant & - \\
\hline
\end{tabular}

Tabel 3 Deskripsi Use Case Diagram Menu Informasi

\begin{tabular}{ll}
\hline Use Case Name & Informasi \\
\hline Requirment & A2 \\
Goal & Sistem menampilkan informasi \\
Pre-condition & $\begin{array}{l}\text { Pengguna memilih menu pada } \\
\text { menu utama }\end{array}$ \\
Post-condition & Sistem menampilkan informasi \\
Failed & Pengguna tidak memilih piihan \\
condition & menu informasi \\
Primary Actor & Pengguna \\
Main Flow/Basic & Pengguna memilih \\
Path & menu informasi \\
Invariant & - \\
\hline
\end{tabular}

Tabel 4. Deskripsi Use Case Diagram Menu Tentang

\begin{tabular}{ll}
\hline Use Case Name & Tentang \\
\hline Requirment & A3 \\
Goal & $\begin{array}{l}\text { Aplikasi menampilkan informasi } \\
\text { mengenai versi program dan nama } \\
\text { pembuatnya }\end{array}$ \\
& $\begin{array}{l}\text { Pengguna memilih menu tentang } \\
\text { pada menu utama }\end{array}$ \\
& Sistem memberikan tampilan \\
Post-condition & mengenai versi program dan nama \\
& pembuatnya \\
Failed end & Pengguna tidak memilih menu \\
condition & tentang \\
Primary Actor & Pengguna \\
Main Flow/Basic & Pengguna memilih menu \\
Path & tentang \\
Invariant & - \\
\hline
\end{tabular}

b. Activity Diagram 


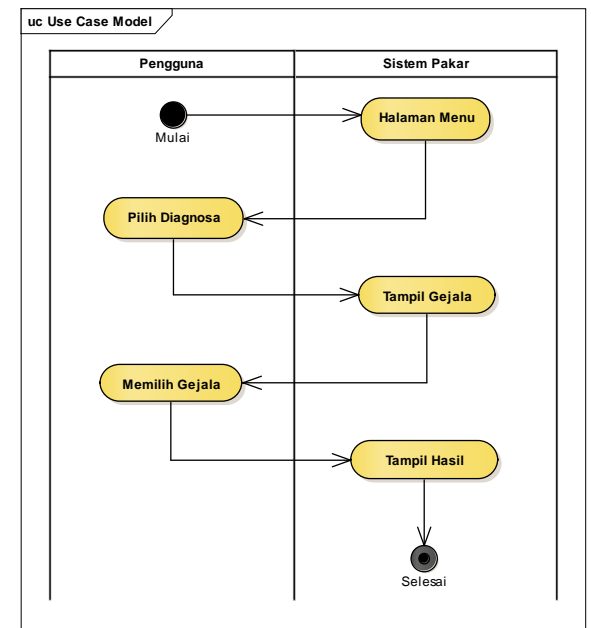

Gambar 6 Activity Diagram Diagnosa

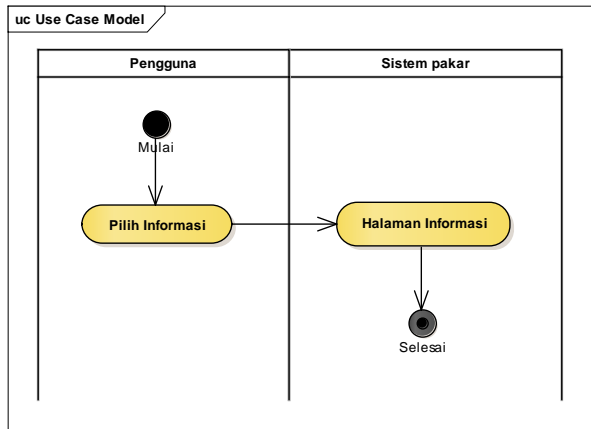

Gambar 7 Activity Diagram Informasi

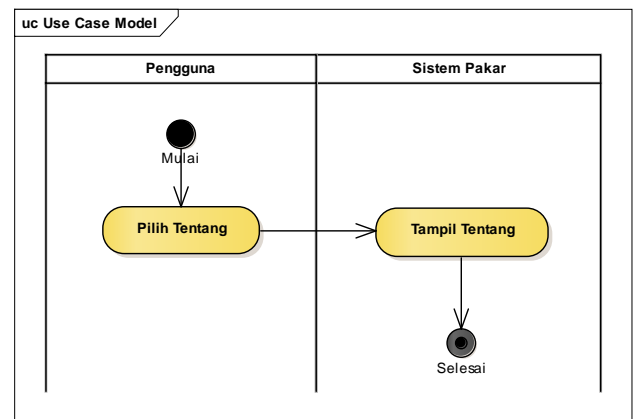

Gambar 8 Activity Diagram Tentang

c. Squance Diagram

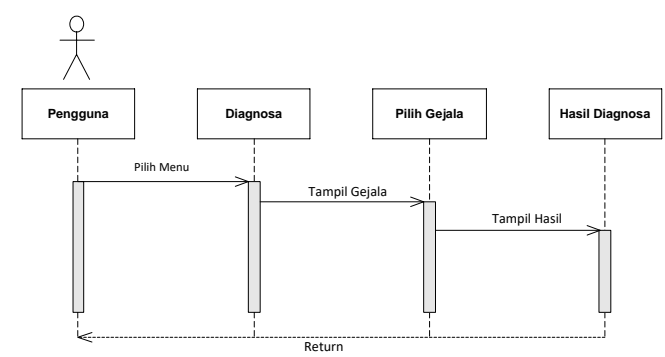

Gambar 9 Secuence Diagram Diagnosa

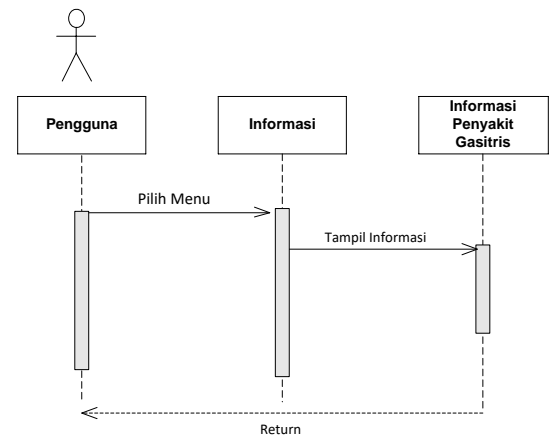

Gambar 10 Secuence Diagram Informasi

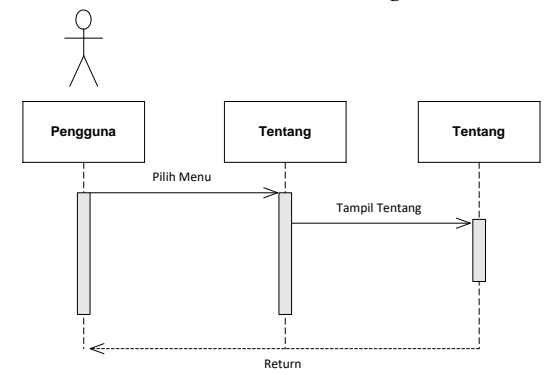

Gambar 11 Secuence Diagram Tentang

d. Deployment Diagram

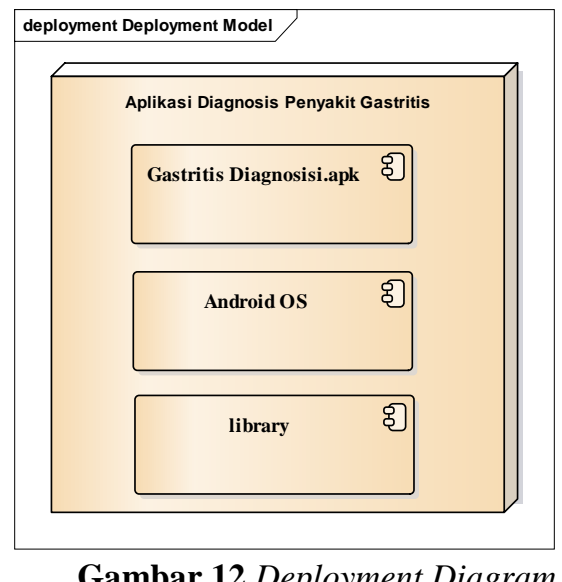

e. USER INTERFACE

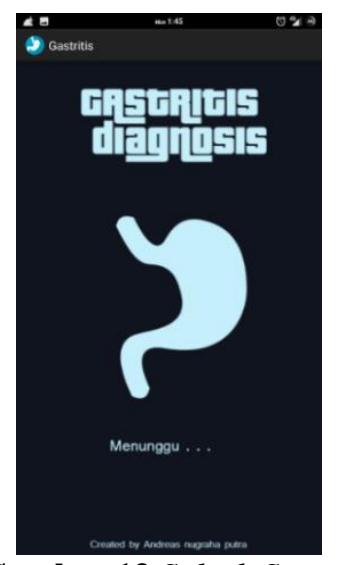

Gambar 13 Splash Screen 


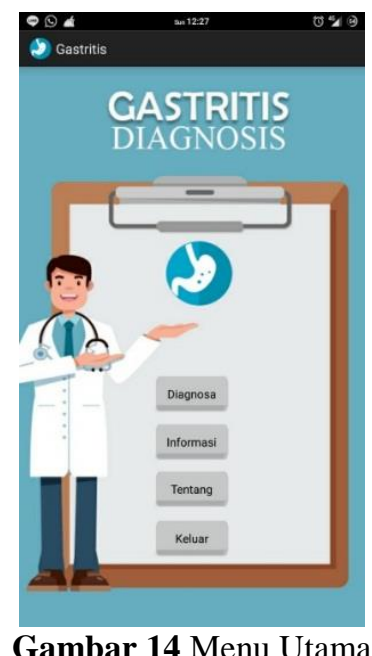

Gambar 14 Menu Utama

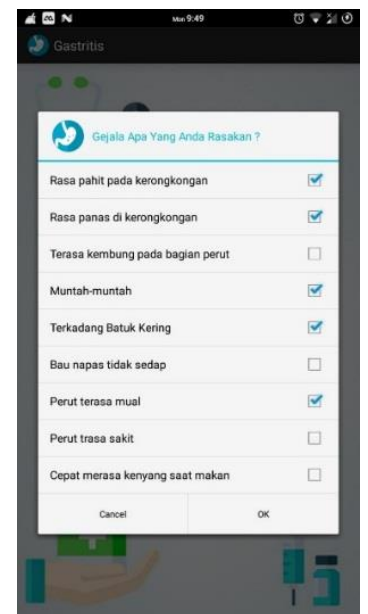

Gambar 15 Pilihan Gejala

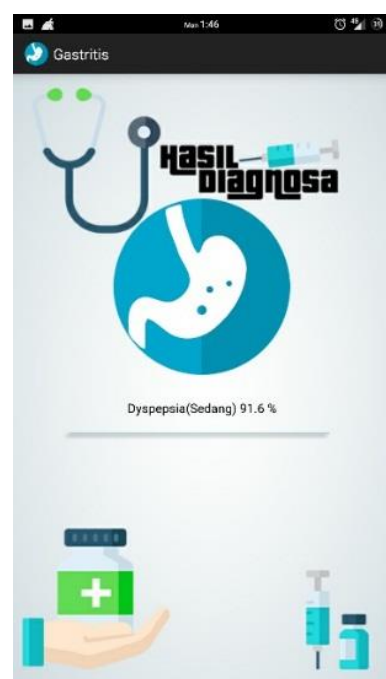

Gambar 16 Hasil Diagnosa

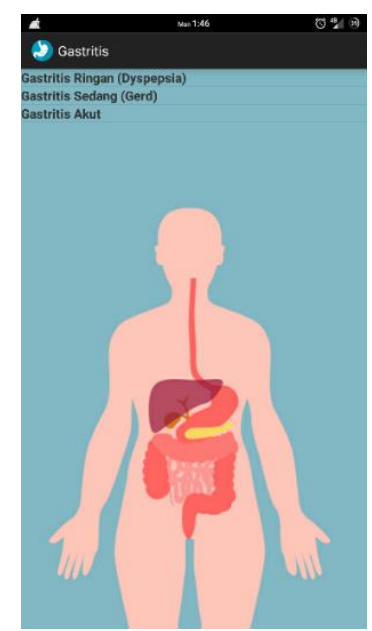

Gambar 17 Informasi Gejala

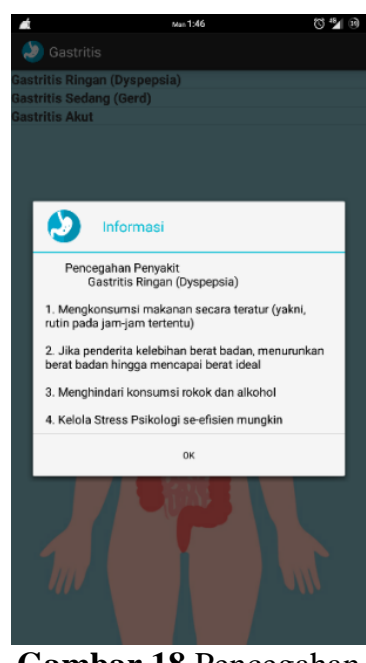

Gambar 18 Pencegahan

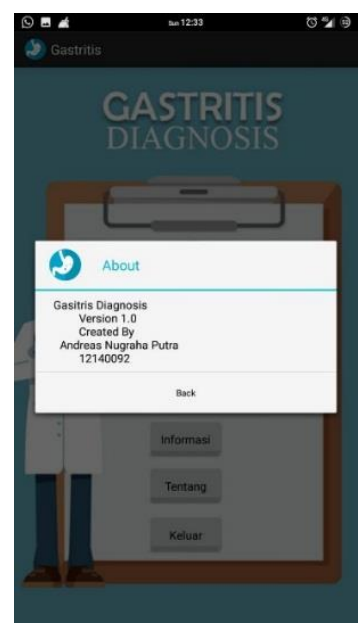

Gambar 19. Tentang 


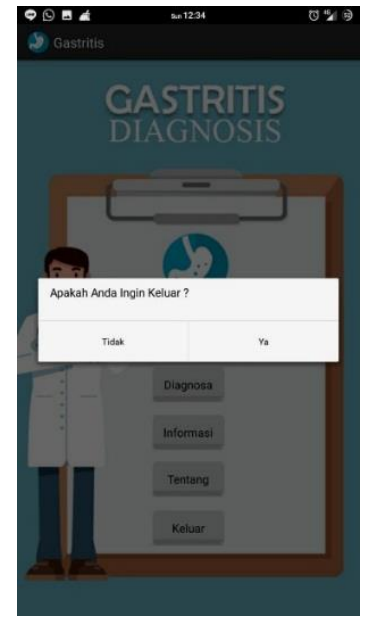

Gambar 20. Keluar

\section{KESIMPULAN}

Sistem pakar ini dibuat untuk membantu pengguna atau pasien, khususnya para remaja yang menderita penyakit gastritis untuk mendapatkan informasi mengenai penyakit gastritis yang dialaminya, sebagai tahap awal untuk mengetahui diagnosis penyakit sebelum pengguna konsultasi dengan dokter. Model pengambilan keputusan dengan Certainty Factor (CF) dapat diimplementasikan untuk melakukan diagnosa terhadap suatu penyakit, karena setiap kesimpulan yang didapat untuk mendiagona berganjung kepada gejala yang dialami oleh pengguna dan Pemodelan UML memudahkan dalam menyusun dan menentukan kebutuhan pengguna dan kebutuhan sistem pada aplikasi.

\section{DAFTAR PUSTAKA}

IDI, "Panduan Praktik Klinis Bagi Dokter di Fasilitas Pelayanan Kesehatan Primer," Menteri Kesehat. Republik Indones., pp. 162, 364, 2017.

[2] D. Wahyu, Supono, and N. Hidayah, "Pola Makan Sehari-hari Penderita Gastritis," J. Inf. Kesehat. Indones., vol. 1, no. 77, pp. 1724, 2015.

[3] N. A. Ritonga, "SISTEM PAKAR MENDIAGNOSA PENYAKIT LAMBUNG," Pelita Inform. Budi Darma, vol. V, no. November, pp. 157-161, 2013.

[4] H. T. Sihotang, "Sistem pakar untuk mendiagnosa penyakit pada tanaman jagung dengan metode bayes," vol. 3, no. 1, 2018.

[5] B. Susetyo, I. Nurhayati, I. Purnahayu, and P. Eosina, "Model Evaluasi Kinerja SDM Geospasial Menggunakan Metode CPI dan CPD Berbasis WebGIS," vol. 2020, 2017.

[6] F. Akbar, S.setiaji, R. Ishak, D. Saputra, and B. Masruri, "Rancang Bangun Sistem Informasi Karang Taruna Menggunakan Metode Waterfall," Khatulistiwa Inform., vol. VIII, no. 1, pp. 7-12, 2020, [Online]. Available: www.bsi.ac.id.

[7] N. Sari and B. Sembiring, "BAKTERI SALMONELLA DALAM TUBUH MANUSIA MENGGUNAKAN METODE CERTAINTY FACTOR," pp. 394-399, 2014.
M. Zunaidi, M. Rasyid, and I. Zulkarnain, "Penerapan Metode Certainty Factor dalam Teknik Photography untuk Menentukan Settingan Kamera DSLR yang Menghasilkan Gambar Terbaik," $J$. Ilm. Saintikom, vol. 14, p. 186, 2015.

[9] J. A. Widians and A. Utomo, "SISTEM PAKAR DIAGNOSA DYSPEPSIA DENGAN CERTAINTY FACTOR,” pp. 6-8, 2015.

[10] H. A. Hidayat and G. Gumilang, "Sistem Pakar Diagnosis Penyakit Yang Disebabkan Oleh Rokok Dengan Metode Forward Chaining," Jutekin, vol. 3, no. 1, pp. 27-36, 2017.

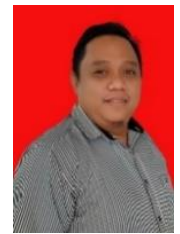

Riswandi Ishak. Ujung Pandang, 14 april 1982. Dosen. Perancangan Enterprise Resource Planning Modul Recruitment menggunakan Oddo pada PT. Kinarya Alihdaya Mandiri. Rancang Bangun Sistem Informasi Penjualan Kue dan Roti Berbasis Web Pada Yuky Bakery Jakarta

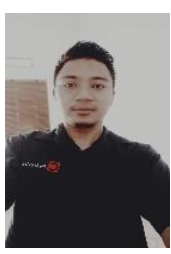

Setiaji. Jakarta, 4 Desember 1987. Dosen ERP, Mengajar di Universitas Bina Sarana Informatika dan Universitas Nusa Mandiri.penulis kajian efektivitas kegiatan belajar mengajar dengan game edukasi studi kasus pada TK (taman kanak-kanan) se kecamatan Ciledug

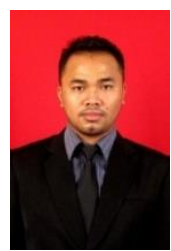

Jamal Maulana Hudin. Sukabumi, 14 Februari 1988. Kajian Keberhasilan Penggunaan Sistem Informasi Accurate Dengan Menggunakan Model Kesuksesan Sistem Informasi Delon Dan Mclean 